\title{
ENGLISH PHRASAL VERBS: DERIVATION AND SEMANTICS
}

\section{Oksana Vorobiova ${ }^{1}$ \\ Larysa Saienko ${ }^{2}$}

DOI: https://doi.org/10.30525/978-9934-588-15-0-107

Abstract. The paper focuses on the analysis of English phrasal verbs, i.e. complex lexemes that consist of a monolexemic verb and a special component of adverbial and prepositional origin standing in the postposition to the verb and forming with it more or less stable semantic and syntactic combinations. The research considers verbs with the postpositive components 'on' and 'off', defines their common and specific semantic and derivational features. The analysis of derivational processes within the verbs with postpositive components on and off enables to distinguish two types of derivation typical of them: word-building derivation (concerns the units which are formed from basic verbs by means of postpositive components on or off) and semantic derivation (the meanings of the units under consideration are formed from already existing meanings in the direction of metaphorization, restriction, extension or complication of meaning with additional semes). In this case, word derivation is more productive for phrasal verbs with both components - on and off. The classification of verbs with postpositive components on and off established in the study includes 8 main semantic types: physical action, phasal, abstract, psycho-mental, emotional, existential, possessive and relational verbs. Productivity of the basic semantic types of these verbs is different. Hence, for the verbs with the postpositive component off, the most common are verbs of physical action while for the verbs with the postpositive component on - psycho-mental verbs. In addition to the common meanings, specific meanings have been distinguished within verbs with the postpositive components on and off, i.e. meanings specific only to verbs with either of the postpositives (typical of solely phrasal verbs with on is the meaning of 'to continue', for those with off - the meaning

\footnotetext{
${ }^{1} \mathrm{PhD}$ in Philology, Associate Professor,

Head of the Department of Germanic Philology and Translation,

National University "Yuri Kondratyuk Poltava Polytechnic", Ukraine

${ }^{2}$ Senior Lecturer at the Department of Germanic Philology and Translation,

National University "Yuri Kondratyuk Poltava Polytechnic", Ukraine

(C) Oksana Vorobiova, Larysa Saienko
} 
of 'to finish'). In this case, the verbs with the postpositive component off are characterized by a wider variety of semantics. Thus, in the semantic system of the verbs with the component off there have been distinguished 25 specific meanings, and in that one of the verbs with the component on - 16 specific meanings. This can be mostly due to the different qualitative and quantitative development level of the semantic structure of the postpositive components on and off. It has been found out also, that between the verbs with the postpositive components on and off there exist relations of antonymy and synonymy, which, in turn, are caused by such factors as the basic semantic opposition of the postpositive components on and off in their primary locative meanings and the possibility of desemantization of the postpositive components and their basic verbs during the formation verbs with postpositive components.

\section{Introduction}

Phrasal verbs represent one of the main features of the English verbal word-formation. They consist of a monolexemic verb and a postpositive component of adverbial and prepositional nature which forms with a verb a relatively stable semantic and syntactic combination owing to the weakening of its adverbial or prepositional function.

Many linguists studied phrasal verbs within a certain scope - in particular, they dwelled on the status of the phrasal verb $(\mathrm{PhV})$, the origin and the nature of the postpositive component (PC), the position of the PC towards the verb and phonetic features of the PhV (Amosova, 1963 [1]; Anichkov, 1961 [2]; Basyrov, 2004 [3]; Berlizon, 1958 [4]; Gurskij, 1975 [6]; Zhluktenko, 1954 [7]), combinability of basic verbs (BV) with postpositives (Kaliushhenko, 1993, 2000 [8; 15]; Klijunajte, 1989 [9]; Stupak, 2011 [10]; Marchand 1967 [17]), cognitive characteristics of PhVs (Trubnikova, 2015 [11]; Talmy, 1991 [19]). However, notwithstanding the above mentioned works, semantics as well as derivational processes within the system of English phrasal verbs have not been analyzed minutely enough. In particular, there appears to be no detailed semantic classification of phrasal verbs as a whole, nor can one observe semantic classifications of phrasal verbs with certain postpositive components. Furthermore, in most studies phrasal verbs are regarded beyond the opposition to their basic verbs. 
Thus, phrasal verbs can be regarded as derivative lexical units formed from corresponding basic verbs (BV) with the help of postpositive components (PC)/postpositives. In this connection one of the most important aspects of studying English phrasal verbs is to consider their derivational peculiarities, in particular, to identify and analyze types of semantic correlation between phrasal verbs and their basic verbs (Vorobyova, 2015, 2017 [20; 5]).

Based on the comparative analysis of some particular phrasal verbs, namely phrasal verbs with postpositive components on and off ( $\mathrm{PhV}$-on and $\mathrm{PhV}$-off), that is lexemes like to turn on, to turn off', the present article is aimed at distinguishing typical semantic and derivational peculiarities of English phrasal verbs. The choice of phrasal verbs with these very postpositives as an object of this study can be accounted for by the fact that these verbal complexes are remarkable in their original semantic opposition, well-developed semantic structure, high productivity and wide use in speech.

\section{Derivational and semantic peculiarities of English phrasal verbs}

The comparative study of $\mathrm{PhV}$-on and $\mathrm{PhV}$-off which run to 1112 units (404 PhV-on and $708 \mathrm{PhV}$-off), taken from definition dictionaries of the English language $[14 ; 18]$, dictionaries of phrasal verbs $[13 ; 16]$ as well as British National Corpus [12] was performed to single out common and distinctive semantic and derivational features in the system of the above mentioned verbal derivatives, typical semantic parallels between them.

2.1. Derivation within PhV-on and PhV-off. The analysis of derivational processes within $\mathrm{PhV}$-on and $\mathrm{PhV}$-off enables to distinguish isomorphic as well as allomorphic features in their systems.

2.1.1 Derivational isomorphism of $\mathrm{PhV}$-on and $\mathrm{PhV}$-off is manifested through:

1) the formation of these verbal derivatives by means of word-building derivation (PhV-on/off are formed from basic verbs (BV) by means of PC-on/ off) and semantic derivation (the meanings of $\mathrm{PhV}$-on/off are developed from the meanings of $\mathrm{PhV}$-on/off which already exist in the direction of their metaphorization, narrowing, widening or modification by additional semes) and

2 ) the presence of 3 following types of system-defined relations between $\mathrm{PhV}$-on/off and their basic verbs: the relations of derivation (the meanings of $\mathrm{PhV}$-on/off are either explicitly or implicitly motivated by the meanings of their basic verbs); the relations of idiomatic character (the meanings of 
$\mathrm{PhV}$-on/off are not motivated by the meanings of their basic verbs and can be, therefore, regarded as set expressions with figurative meanings); the relations of equivalence (the meanings of the basic verbs and $\mathrm{PhV}$-on/off are identical, PC-on/off are completely deprived of their lexical meanings and perform the function of the intensifying particle, modifying the meaning of the basic verb). The most productive for both $\mathrm{PhV}$-on and $\mathrm{PhV}$-off appear to be the relations of derivation that can be accounted for by the original derivative nature of these lexical units.

2.1.2 Allomorphism within the derivational systems of the phrasal verbs under study can be proved by: 1) the fact that different word-forming models appear to be productive for $\mathrm{PhV}$-on and $\mathrm{PhV}$-off and 2) more productive in quantitative as well as qualitative relations semantic derivation within $\mathrm{PhV}$-off. While speaking about the productivity of word-forming models for $\mathrm{PhV}$-on and $\mathrm{PhV}$-off, it is necessary to mention that the most productive, typical of PhV-off exclusively, is the model "BV of movement + PC-off with the meaning of 'away from (the place)' $\rightarrow$ PhV-off with the meaning of 'to leave a place in the way expressed by the BV" "while for $\mathrm{PhV}$-on the most typical is the model "BV of movement / social activity of a person + PC-on with the meaning of 'continuation of the action' $\rightarrow \mathrm{PhV}$-on with the meaning of 'the continuation of the action, expressed by the BV"'). As for the higher productivity of semantic derivation within PhV-off, it should be noted that the possibility of semantic derivation within $\mathrm{PhV}$-on is confined only to metaphorization and narrowing of the already existing meanings of PhV-on while PhV-off can develop their meanings not only in the direction of their metaphorization and narrowing, but also widening or modification by additional semes.

The next tables give a general vision of derivational processes which occur within $\mathrm{PhV}$-on and $\mathrm{PhV}$-off

2.2. Semantics of PhV-on and PhV-off. The principal semantic characteristic in common for $\mathrm{PhV}$-on and $\mathrm{PhV}$-off is the functioning of these verbal combinations within 8 common semantic types and coming from this the presence of 8 typical meanings of $\mathrm{PhV}$-on/off, which, on their turn, are represented by common meanings of semantic subtypes, groups and subgroups.

The heterogeneity of the semantic structure of PhV-on and PhV-off, which is manifested through the presence of specific semantic types and meanings in their systems, is the main distinguishing semantic feature of these verbal complexes. 
Table 1

Types of Derivation within $\mathrm{PhV}$-on and $\mathrm{PhV}$-off

\begin{tabular}{|c|l|c|c|}
\hline № & \multicolumn{1}{|c|}{ Type of Derivation } & $\begin{array}{c}\text { The number } \\
\text { of PhV-on }\end{array}$ & $\begin{array}{c}\text { The number } \\
\text { of PhV-off }\end{array}$ \\
\hline 1. & $\begin{array}{l}\text { Word-forming Derivation } \\
\text { (certain changes in the semantics of BVs at the } \\
\text { formation of PhV-on and PhV-off }\end{array}$ & $395(97,8 \%)$ & $610(86,2 \%)$ \\
\hline 2. & $\begin{array}{l}\text { Semantic Derivation } \\
\text { (certain changes within already existing meanings of } \\
\text { PhV-on/off at the formation of their new meanings) }\end{array}$ & $9(2,2 \%)$ & $98(13,8 \%)$ \\
\hline & \multicolumn{1}{|c|}{ Total } & $\mathbf{4 0 4 ( 1 0 0 \% )}$ & $\mathbf{7 0 8 ( 1 0 0 \% )}$ \\
\hline
\end{tabular}

Table 2

Means of Word-forming Derivation within PhV-on and PhV-off

\begin{tabular}{|c|c|c|c|c|c|}
\hline \multirow{2}{*}{ № } & \multirow{2}{*}{$\begin{array}{c}\text { Means of } \\
\text { Word-forming } \\
\text { Derivation }\end{array}$} & \multicolumn{2}{|l|}{ PhV-on } & \multicolumn{2}{|c|}{ PhV-off } \\
\hline & & Example & Number & Example & Number \\
\hline 1. & $\begin{array}{l}\text { The Presence of } \\
\text { Word-forming } \\
\text { Derivation } \\
\text { (partial or full change } \\
\text { of the meanings } \\
\text { of the BVs at the } \\
\text { formation of PhV-on/ } \\
\text { off from them) }\end{array}$ & & $\begin{array}{c}384 \\
(97,2 \%)\end{array}$ & & $\begin{array}{c}534 \\
(87,5 \%)\end{array}$ \\
\hline 1.1. & $\begin{array}{l}\text { The Presence } \\
\text { of Semantic } \\
\text { Connection } \\
\text { (the possibility to } \\
\text { derive the meanings } \\
\text { of PhV-on/off from } \\
\text { the meanings of their } \\
\text { BVs) }\end{array}$ & & $\begin{array}{c}277 \\
(\mathbf{7 0 , 1 \%} \%\end{array}$ & & $\begin{array}{c}414 \\
(67,8 \%)\end{array}$ \\
\hline 1.1.1. & $\begin{array}{l}\text { Explicit motivation } \\
\text { (full reproduction } \\
\text { of the meanings } \\
\text { of BVs in } \\
\text { the PhV-on/off's } \\
\text { semantics) }\end{array}$ & $\begin{array}{l}\text { to ride on 'to con- } \\
\text { tinue riding } \leftarrow \\
\text { to ride 'to travel } \\
\text { along, controlling } \\
\text { and sitting on (a } \\
\text { horse or other } \\
\text { animal, a bicycle, } \\
\text { or a motorcycle)' }\end{array}$ & $\begin{array}{c}70 \\
(17,7 \%)\end{array}$ & $\begin{array}{l}\text { to hack off 'to } \\
\text { remove by } \\
\text { hacking } \leftarrow \text { to } \\
\text { hack 'to cut } \\
\text { with a knife or } \\
\text { smth. sharp, } \\
\text { in a rough and } \\
\text { careless way)' }\end{array}$ & $\begin{array}{c}169 \\
(27,7 \%)\end{array}$ \\
\hline
\end{tabular}


Continuation of Table 2

\begin{tabular}{|c|c|c|c|c|c|}
\hline 1.1.2. & $\begin{array}{l}\text { Implicit } \\
\text { motivation }\end{array}$ & & $\begin{array}{c}207 \\
(52,4 \%)\end{array}$ & & $\begin{array}{c}245 \\
(40,1 \%)\end{array}$ \\
\hline 1.1.2.1. & $\begin{array}{l}\text { the possibility } \\
\text { to re-interpret } \\
\text { the meanings of } \\
\mathrm{PhV-on/off} \mathrm{and} \\
\text { their BVs }\end{array}$ & $\begin{array}{l}\text { to bank on 'to rely } \\
\text { on smb./smth. (to } \\
\text { have confidence } \\
\text { in)' } \leftarrow \text { to bank'to } \\
\text { keep money (in } \\
\text { a bank)' (if one } \\
\text { keeps money in a } \\
\text { bank, they rely on } \\
\text { this service (i.e. } \\
\text { have confidence } \\
\text { in it)) }\end{array}$ & $\begin{array}{c}171 \\
(43,3 \%)\end{array}$ & $\begin{array}{l}\text { to pack off 'to } \\
\text { send smb. to } \\
\text { a place, usu. } \\
\text { without asking } \\
\text { them if they } \\
\text { want to go } \leftarrow \\
\text { to pack' to put } \\
\text { (things, esp. } \\
\text { one's belong- } \\
\text { ings) into cases, } \\
\text { boxes, etc., } \\
\text { usu. for taking } \\
\text { somewhere' }\end{array}$ & $\begin{array}{c}181 \\
(29,6 \%)\end{array}$ \\
\hline 1.1.2.2. & $\begin{array}{l}\text { the presence of } \\
\text { a common seme } \\
\text { or semes in the } \\
\text { semantics of } \\
\mathrm{PhV-on/off} \mathrm{and} \\
\text { their BVs }\end{array}$ & $\begin{array}{l}\text { to hop on 'to } \\
\text { throw smth. (i.e. } \\
\text { to cause smth. } \\
\text { to move, usu. } \\
\text { forward)' } \leftarrow \text { to } \\
\text { hop 'to jump (= } \\
\text { to move oneself } \\
\text { into the air by } \\
\text { the force of one's } \\
\text { legs)' }\end{array}$ & $\begin{array}{c}36 \\
(9,1 \%)\end{array}$ & $\begin{array}{l}\text { to skip off 'to } \\
\text { leave (i.e. to } \\
\text { move away } \\
\text { from) a place } \\
\text { suddenly, esp. } \\
\text { when you } \\
\text { should not' } \\
\leftarrow \text { to skip 'to } \\
\text { move in a light } \\
\text { dancing way } \\
\end{array}$ & $\begin{array}{c}64 \\
(10,5 \%)\end{array}$ \\
\hline 1.2. & $\begin{array}{l}\text { The Absence } \\
\text { of Semantic } \\
\text { Connection } \\
\text { (no possibility } \\
\text { to derive the } \\
\text { meanings of } \\
\text { PhV-on/off from } \\
\text { the meanings of } \\
\text { their BVs }\end{array}$ & $\begin{array}{l}\text { to round on 'to } \\
\text { criticize, usu. } \\
\text { sharply' } \\
\leftarrow \text { to round } \\
\text { 'to make smth. } \\
\text { round' (the mean- } \\
\text { ing of PhV-on } \\
\text { and its BV are } \\
\text { not sematically } \\
\text { related) }\end{array}$ & $\begin{array}{c}107 \\
(27,1 \%)\end{array}$ & $\begin{array}{l}\text { to blow off } \\
\text { 'to cancel (an } \\
\text { event)' } \leftarrow \text { to } \\
\text { blow 'to send } \\
\text { out a strong } \\
\text { current of air' } \\
\text { (the meaning } \\
\text { of PhV-on and } \\
\text { its BV are not } \\
\text { sematically } \\
\text { related) } \\
\end{array}$ & $\begin{array}{c}120 \\
(19,7 \%)\end{array}$ \\
\hline 2. & $\begin{array}{l}\text { The Absence of } \\
\text { Word-forming } \\
\text { Derivation } \\
\text { (the meanings of } \\
\text { PhV-on/off and } \\
\text { their BVs are } \\
\text { identical) } \\
\end{array}$ & $\begin{array}{l}\text { to cheer on 'to } \\
\text { express approval } \\
\text { or support, to } \\
\text { encourage' } \leftarrow \text { to } \\
\text { cheer 'to express } \\
\text { approval or sup- } \\
\text { port, to encourage' }\end{array}$ & $\begin{array}{c}11 \\
(2,8 \%)\end{array}$ & $\begin{array}{l}\text { to auction off } \\
\text { 'to sell smth. at } \\
\text { an auction' } \longleftarrow \\
\text { to auction 'to } \\
\text { sell smth. at an } \\
\text { auction' }\end{array}$ & $\begin{array}{c}76 \\
(12,5 \%)\end{array}$ \\
\hline & Total & & $\begin{array}{c}395 \\
(100 \%)\end{array}$ & & $\begin{array}{c}610 \\
(100 \%)\end{array}$ \\
\hline
\end{tabular}


2.2.1 PhV-on and PhV-off share 8 following semantic types: physical, mental-psychological, abstract, emotive, possessive, phasal, relative and existential $\mathrm{PhV}$-on/off. The degree of productivity within these principal semantic types of $\mathrm{PhV}$-on and $\mathrm{PhV}$-off varies. The most productive in the semantic system of $\mathrm{PhV}$-on are mentalpsychological verbs, e.g. to dwell on 'to think about something for too long, especially about something that is unpleasant' (the verb of mental activity); to carry on 'to behave in a silly or excited way' (the verb of psychological activity, namely the verb of behaviour). In the system of PhV-off, however, these are the verbs of physical action, e.g. to run off 'to leave somewhere by running, usually to avoid being caught' (the verb of movement, namely moving away); to rub off 'to remove something from a surface by rubbing it' (locative verb with the additional meaning of physical impact).

Phrasal verbs under consideration differ in two semantic types, which are the verbs of sense perception; such as, to happen on 'to catch sight of something or somebody, usually unexpectedly' exclusively for PhV-on and physiological verbs; such as, to nod off 'to fall asleep when you do not intend to' solely for PhV-off.

2.2.2 Common typical meanings of PhV-on and PhV-off naturally coincide with the above mentioned common semantic types and stand for 8 following meanings: physical action, mental-psychological action, abstract action, emotive action, possession, phase of the action, relativeness and existence. In their turn, they are expressed through common meanings of the following subtypes, groups and subgroups: physical action $\rightarrow$ movement (movement proper, causation of movement) and location (causation of location); mental-psychological action $\rightarrow$ speaking, mental activity and behaviour; abstract action $\rightarrow$ change of the quality (change of the quality proper, causation of change of the quality), abstract usage and successful accomplishment of the action; emotive action (causation of feeling); possession (causation of possession, the beginning of possession); phase of the action (the beginning of the action); relativity (interpersonal relations, correlation); existence (creation).

The table below illustrates quite well the above mentioned thesis.

As it can be seen from the examples in Table 1, even though PhV-on and $\mathrm{PhV}$-off have typical meanings in common, these meanings are usual- 
Table 3

Common Typical Meanings of PhV-on and PhV-off

\begin{tabular}{|c|c|c|c|c|c|}
\hline \multirow{2}{*}{ № } & \multirow{2}{*}{ Typical meaning } & \multicolumn{2}{|c|}{ PhV-on } & \multicolumn{2}{|c|}{ PhV-off } \\
\hline & & Example & Number & Example & Number \\
\hline 1. & physical action & & $\begin{array}{c}54 \\
(19,5 \%) \\
\end{array}$ & & $\begin{array}{c}216 \\
(54,7 \%) \\
\end{array}$ \\
\hline 1.1. & movement & & $\begin{array}{c}26 \\
(9,4 \%)\end{array}$ & & $166(42 \%)$ \\
\hline 1.1 .1 . & movement proper & to pass on & $\begin{array}{c}14 \\
(5,1 \%) \\
\end{array}$ & to speed off & $11629,3 \%)$ \\
\hline 1.1 .2 . & $\begin{array}{l}\text { causation of move- } \\
\text { ment }\end{array}$ & $\begin{array}{l}\text { to move (smb.) } \\
\text { on }\end{array}$ & $\begin{array}{c}12 \\
(4,3 \%) \\
\end{array}$ & $\begin{array}{l}\text { to push } \\
\text { (smb.) off }\end{array}$ & $50(12,7 \%)$ \\
\hline 1.2 . & $\begin{array}{l}\text { location } \\
\text { (causation of location) }\end{array}$ & $\begin{array}{l}\text { to throw } \\
\text { (smth.) on }\end{array}$ & $\begin{array}{c}28 \\
(10,1 \%)\end{array}$ & $\begin{array}{l}\text { to throw } \\
\text { (smth.) off }\end{array}$ & $50(12,7 \%)$ \\
\hline 2. & $\begin{array}{l}\text { mental-psychological } \\
\text { action }\end{array}$ & & $\begin{array}{c}90 \\
(32,5 \%)\end{array}$ & & $\begin{array}{c}42 \\
(10,6 \%)\end{array}$ \\
\hline 2.1 . & speaking & to hammer on & $\begin{array}{c}43 \\
(15,5 \%)\end{array}$ & to reel off & $21(5,3 \%)$ \\
\hline 2.2 & mental activity & $\begin{array}{l}\text { to cotton on } \\
\text { (smth.) }\end{array}$ & $\begin{array}{c}32 \\
(11,6 \%)\end{array}$ & $\begin{array}{l}\text { to brush } \\
\text { (smth.)off }\end{array}$ & $13(3,3 \%)$ \\
\hline 2.3 & behaviour & to gam on & $\begin{array}{c}15 \\
(5,4 \%)\end{array}$ & to take off & $8(2 \%)$ \\
\hline 3. & abstract action & & $\begin{array}{c}31 \\
(11,2 \%)\end{array}$ & & $28(7,1 \%)$ \\
\hline 3.1 . & change of the quality & & $\begin{array}{c}14 \\
(5,1 \%)\end{array}$ & & $15(3,8 \%)$ \\
\hline 3.1 .1$. & $\begin{array}{l}\text { change of the quality } \\
\text { proper }\end{array}$ & to get on & $\begin{array}{c}10 \\
(3,6 \%) \\
\end{array}$ & to taper off " & $7(1,8 \%)$ \\
\hline 3.1 .2 & $\begin{array}{l}\text { causation of change } \\
\text { of the quality }\end{array}$ & to put on & $\begin{array}{c}4 \\
(1,5 \%)\end{array}$ & to wipe off " & $8(2 \%)$ \\
\hline 3.2 . & abstract usage & $\begin{array}{l}\text { to poll on } \\
\text { (smth.) }\end{array}$ & $\begin{array}{c}12 \\
(4,3 \%) \\
\end{array}$ & $\begin{array}{c}\text { to live off } \\
\text { (smth.) }\end{array}$ & $8(2 \%)$ \\
\hline 3.3 . & $\begin{array}{l}\text { successful accom- } \\
\text { plishment } \\
\text { of the action }\end{array}$ & to take on & $\begin{array}{c}5 \\
(1,8 \%)\end{array}$ & to take off & $5(1,3 \%)$ \\
\hline 4. & $\begin{array}{l}\text { emotive action } \\
\text { (causation of feeling) }\end{array}$ & $\begin{array}{l}\text { to bring } \\
\text { (smb.) on }\end{array}$ & $\begin{array}{c}37 \\
(13,3 \%) \\
\end{array}$ & $\begin{array}{c}\text { to tick (smb.) } \\
\text { off }\end{array}$ & $\begin{array}{c}16 \\
(4,1 \%) \\
\end{array}$ \\
\hline 5. & possession & & $11(4 \%)$ & & $34(8,6 \%)$ \\
\hline 5.1. & $\begin{array}{l}\text { causation of posses- } \\
\text { sion }\end{array}$ & $\begin{array}{l}\text { to hand } \\
\text { (smth.) on }\end{array}$ & $7(2,5 \%)$ & $\begin{array}{c}\text { to buy smb. } \\
\text { off }\end{array}$ & $17(4,3 \%)$ \\
\hline
\end{tabular}


Continuation of Table 3

\begin{tabular}{|c|c|c|c|c|c|}
\hline 5.2 . & $\begin{array}{l}\text { the beginning } \\
\text { of possession }\end{array}$ & $\begin{array}{l}\text { to queer on } \\
\text { (smb.) }\end{array}$ & $4(1,5 \%)$ & $\begin{array}{c}\text { to cream off } \\
\text { (smth.) }\end{array}$ & $17(4,3 \%)$ \\
\hline 6. & $\begin{array}{l}\text { phase of the action } \\
\text { (the beginning } \\
\text { of the action) }\end{array}$ & to come on & $\begin{array}{c}26 \\
(9,4 \%)\end{array}$ & to kick off & $\begin{array}{c}18 \\
(4,5 \%)\end{array}$ \\
\hline 7. & relativity & & $25(9 \%)$ & & $16(4,1 \%)$ \\
\hline 7.1 . & interpersonal relations & $\begin{array}{l}\text { to call on } \\
\text { (smb.) }\end{array}$ & $\begin{array}{c}18 \\
(6,5 \%)\end{array}$ & $\begin{array}{c}\text { to help (smb.) } \\
\text { off }\end{array}$ & $9(2,3 \%)$ \\
\hline 7.2 . & correlation & $\begin{array}{l}\text { to ride on } \\
\text { (smb./sth.) }\end{array}$ & $7(2,5 \%)$ & to trade off & $\begin{array}{c}7 \\
(1,8 \%) \\
\end{array}$ \\
\hline \multirow[t]{2}{*}{8.} & $\begin{array}{l}\text { existence } \\
\text { (creation) }\end{array}$ & $\begin{array}{c}\text { to lay(smth.) } \\
\text { on }\end{array}$ & $\begin{array}{c}3 \\
(1,1 \%)\end{array}$ & $\begin{array}{l}\text { to let (smth.) } \\
\text { off(smb./sth.) }\end{array}$ & $\begin{array}{c}25 \\
(6,3 \%)\end{array}$ \\
\hline & Total & & $\begin{array}{c}277 \\
(100 \%)\end{array}$ & & $\begin{array}{c}395 \\
(100 \%)\end{array}$ \\
\hline
\end{tabular}

ly modified by some additional semes which vary for $\mathrm{PhV}$-on and $\mathrm{PhV}$-off within one and the same typical meaning. Thus, the principal difference in the semantics of PhV-on and PhV-off of movement lies in the fact that $\mathrm{PhV}$-off of this kind are most likely to express 'leaving a place (quite often in a way implied by the basic verb)' while such PhV-on mostly denote 'moving forward'. This phenomenon can be primarily explained by full implementation of spatial semantics inherent to postpositive components on and off. Besides, the basic seme of movement within the subtype "movement proper" is modified by a bigger number of extra semes denoting the manner of this movement in the system of PhV-off (here refer such semes as 'away (from a place)', 'leaving smb. behind', 'slowly', 'backwards', 'from inside into outside') compared with PhV-on (only two semes can be suggested: 'fast' and 'following somebody'). Verbs of the second subtype implying causation of movement share more common features than the verbs denoting movement proper. In particular, they both can express "enforcement to leave a place". Locative PhV-on and $\mathrm{PhV}$-off, for which isomorphic is the meaning of causation of location, demonstrate opposition as for the locative component of the meaning of the verbs ('onto the surface' - 'off, away from the surface').

Dwelling on the abstract meanings of phrasal verbs in question, it should be mentioned that such figurative $\mathrm{PhV}$-on and $\mathrm{PhV}$-off demon- 
strate clearer isomorphism in comparison with $\mathrm{PhV}$-on and $\mathrm{PhV}$-off of direct "physical" semantics and differ only within particular definitions (see examples in Table 1). This can be accounted for by the process of desemantization of the postpositives, which together with basic verbs that lose their direct nominative meanings, form more stable (quite often idiomatic) in terms of semantics lexical units. The most notable thing in this respect is the possibility to single out mostly partial synonymy, especially within $\mathrm{PhV}$-on and $\mathrm{PhV}$-off denoting abstract usage, successful accomplishment of the action, causation of possession, the beginning of possession and phase of the action (the beginning of the action). At the same time other PhV-on and PhV-off of "abstract" semantics may also reveal allomorphic features. Here we can speak about certain connotations in the semantic structure of PhV-on and PhV-off implying change of the quality proper and causation of change of the quality as well as emotive PhVs. On the whole, opposite to $\mathrm{PhV}$-on which in most cases express the intensification of the quality and positive emotions, $\mathrm{PhV}$-off indicate the lessening of the quality and negative emotions respectively (see examples in Table 1).

Detailed semantic classification of PhV-on and PhV-off enables to claim, that $\mathrm{PhV}$-off can be characterized by more versatile semantics. Thus, the system of PhV-off contain 22 specific meanings, the most productive of which are "separation / causation of separation", "finishing / termination of the action", "destruction"), e.g. to drop off "to get separated from something by dropping', to fence off 'to separate with a fence', to clock off 'to finish work (especially at a stated time)', to break off 'to stop doing something, especially suddenly', to blast off 'to destroy with an explosion'. At the same time, $\mathrm{PhV}$-on have only 16 specific meanings among which the most distinct are "physical impact", "continuation of the action", "location proper"), e.g. to round on "to suddenly attack somebody physically when they do not expect it', to press on 'to continue doing something steadily and persistently', to linger on 'to stay somewhere for a long time, or longer than expected'. The reason for this is that postpositive components on and off are endowed with peculiar semantic features, namely, different qualitative and quantitative level of their semantic structure development (PC-off has a wider semantic structure than PC-on). 
2.2.3 The comparative analysis of PhV-on and PhV-off semantics was also aimed to single out and study synonymic and antonymic relations typical of these verbal complexes.

2.2.3.1 The principal spatial meanings of postpositives on and off are 'onto the surface' for PC-on and 'away from the surface' for PC-off. It is this particular opposition that accounts for the presence of antonymic relations between $\mathrm{PhV}$-on and $\mathrm{PhV}$-off. It should be emphasized that these are the above mentioned meanings of PC-on and PC-off that assume the main differential semantic potential, as in overwhelming majority of cases derivational basis of these phrasal verbs is made up by the same basic verbs, e.g. to sign 'to give a sign' $\rightarrow$ to sign on 1) 'to give a sign to start a TV or radio broadcasting'; 2) to sign off 'to give a sign to finish a TV or radio broadcasting' (in this case direct spatial meanings of PC-on and PC-off are transformed into phasal meanings of beginning and finishing the action expressed by the basic verb.

Antonymic relations between $\mathrm{PhV}$-on and $\mathrm{PhV}$-off can be observed within 3 types of phrasal verbs under consideration, namely, locative and phasal $\mathrm{PhV}$-on/off as well as $\mathrm{PhV}$-on/off of functioning (verbs of physical action). They are manifested through 2 following semantic oppositions: "the beginning of the action - the finishing of the action" (primary opposition) and "causation of the beginning of the action causation of the finishing of the action" (secondary opposition). Among some special means of achieving semantic opposition it is also possible to distinguish

1) modification of the opposite phasal meanings "the beginning / the finishing of the action" by an additional causative seme ("the beginning / the finishing of the action $\rightarrow$ causation of the beginning / the finishing of the action") and

2) concretization of the phasal meaning "the finishing of the action" ("the finishing of the action" $\rightarrow$ "the termination of the action", where "the termination of the action" implies its sudden and unexpected "finishing"). The total number of $\mathrm{PhV}$-on and $\mathrm{PhV}$-off marked by antonymic relations is 39 lexical units (20 PhV-on and $19 \mathrm{PhV}$-off).

The table below provides more general information about the antonymy within $\mathrm{PhV}$-on and $\mathrm{PhV}$-off. 
Table 4

Antonymic Relations within PhV-on and PhV-off

\begin{tabular}{|c|c|c|c|c|c|}
\hline \multirow[t]{2}{*}{ No } & \multirow{2}{*}{$\begin{array}{c}\text { Semantic type } \\
\text { of PhV-on and } \\
\text { PhV-off }\end{array}$} & \multicolumn{2}{|l|}{ PhV-on } & \multicolumn{2}{|l|}{$\mathbf{P h V}$-off } \\
\hline & & Example & Number & Example & Number \\
\hline 1. & $\begin{array}{l}\text { Locative } \\
\text { (causation of the } \\
\text { beginning of loca- } \\
\text { tion - causation of } \\
\text { the termination of } \\
\text { location) }\end{array}$ & $\begin{array}{l}\text { to draw on 'to } \\
\text { put (e.g. shoes, } \\
\text { clothes) on your } \\
\text { body by pulling } \\
\text { them' } \leftarrow \text { to draw } \\
\text { 'to move by } \\
\text { pulling' }\end{array}$ & $\begin{array}{c}9 \\
(45 \%)\end{array}$ & $\begin{array}{l}\text { to draw off } \\
\text { 'to remove } \\
\text { smth. that you } \\
\text { are wearing by } \\
\text { pulling them' } \leftarrow \\
\text { to draw 'to move } \\
\text { by pulling' }\end{array}$ & $\begin{array}{c}8 \\
(42,1 \%)\end{array}$ \\
\hline 2. & $\begin{array}{l}\text { Functioning } \\
\text { (causation of the } \\
\text { beginning of func- } \\
\text { tioning - causation } \\
\text { of the termination } \\
\text { of functioning }\end{array}$ & $\begin{array}{l}\text { to switch on } \\
\text { 'to make a light, } \\
\text { machine or engine } \\
\text { start working by } \\
\text { pressing a switch' } \\
\leftarrow \text { to switch } \\
\text { 'to change or } \\
\text { move by a switch' }\end{array}$ & $\begin{array}{c}7 \\
(35 \%)\end{array}$ & $\begin{array}{l}\text { to turn off } \\
\text { 'to make a light, } \\
\text { machine or engine } \\
\text { stop working by } \\
\text { pressing a switch' } \\
\leftarrow \text { to switch } \\
\text { 'to change or } \\
\text { move by a switch' }\end{array}$ & $\begin{array}{c}7 \\
(36,8 \%)\end{array}$ \\
\hline 3. & $\begin{array}{l}\text { Phasal } \\
\text { (the beginning of } \\
\text { the action - the } \\
\text { finishing of the } \\
\text { action) }\end{array}$ & $\begin{array}{l}\text { to clock on } \\
\text { 'to start work } \\
\text { (esp. at a stated } \\
\text { time)' } \leftarrow \text { to clock } \\
\text { 'to record the } \\
\text { time' }\end{array}$ & $\begin{array}{c}4 \\
(20 \%)\end{array}$ & $\begin{array}{l}\text { to clock off 'to fin- } \\
\text { ish work (esp. At a } \\
\text { stated time)' } \leftarrow \\
\text { 'to record the } \\
\text { time' }\end{array}$ & $\begin{array}{c}4 \\
(21,1 \%)\end{array}$ \\
\hline & Total & & $\begin{array}{c}20 \\
(100 \%)\end{array}$ & & $\begin{array}{c}19 \\
(100 \%)\end{array}$ \\
\hline
\end{tabular}

2.2.3.2 Synonymic relations within $\mathrm{PhV}$-on and $\mathrm{PhV}$-off are typical of 5 types of these complexes, namely physical, abstract, possessive, phasal and emotive PhV-on/off. Synonymy between PhV-on and PhV-off appears to be possible due to desemantization of postpositives which get combined with basic verbs, change their meanings and form with these verbs stable expressions with figurative meanings. Normally, derivational basis for such $\mathrm{PhV}$-on and PhV-off is made up by different verbs, e.g. to pick on 'to bother, to disturb' $\leftarrow$ to pick 'to hollow, to pierce' and to tick off 'to bother, to irritate, to make angry' $\leftarrow$ to tick 'to make a regularly repeated short sudden sound'. However, one can come across partially synonymous $\mathrm{PhV}$-on and $\mathrm{PhV}$-off which are based on the same verbs, e.g. to sell on 'to sell something to another person 
soon after you have bought it' and to sell off 'to sell all or part of an industry or company' are both derived from the verb to sell having the meaning of 'to give or pass (property or goods) to someone else in exchange for money'.

The examples given above serve to confirm two ideas: 1) the possibility of desemantization of basic verbs and postpositive components during the formation of phrasal verbs as well as 2) the so-called non-motivated use of PCs when the latter lose their direct nominative meanings and start modifying the meanings of basic verbs which, in their turn, remain unchanged. The total number of such PhV-on and PhV-off run to 21 units (10 PhV-on and $11 \mathrm{PhV}$-off).

The following table clearly illustrates the above mentioned theses.

\section{Synonymic Relations within $\mathrm{PhV}$-on and $\mathrm{PhV}$-off}

Table 5

\begin{tabular}{|c|c|c|c|c|c|}
\hline \multirow[t]{2}{*}{ № } & \multirow{2}{*}{$\begin{array}{c}\text { Semantic type of } \\
\text { PhV-on and PhV-off }\end{array}$} & \multicolumn{2}{|l|}{ PhV-on } & \multicolumn{2}{|c|}{$\mathbf{P h V}$-off } \\
\hline & & Example & Number & Example & Number \\
\hline 1. & $\begin{array}{l}\text { Possesssive } \\
\text { (causation of } \\
\text { possession) }\end{array}$ & $\begin{array}{l}\text { to sell on 'to sell } \\
\text { smth. to another } \\
\text { person soon after } \\
\text { you have bought it' }\end{array}$ & $\begin{array}{c}2 \\
(20 \%)\end{array}$ & $\begin{array}{l}\text { sell off 'to sell } \\
\text { all or part of } \\
\text { an industry or } \\
\text { company' }\end{array}$ & $\begin{array}{c}3 \\
(27,2 \%)\end{array}$ \\
\hline 2. & $\begin{array}{l}\text { Phasal } \\
\text { (the beginning } \\
\text { of the action) }\end{array}$ & $\begin{array}{l}\text { to come on 'to } \\
\text { start (about the } \\
\text { program, season, } \\
\text { event, etc.)' }\end{array}$ & $\begin{array}{c}2 \\
(20 \%)\end{array}$ & $\begin{array}{l}\text { kick off 'to } \\
\text { start (about the } \\
\text { event, etc.)' }\end{array}$ & $\begin{array}{c}2 \\
(18,2 \%)\end{array}$ \\
\hline 3. & $\begin{array}{l}\text { Physical } \\
\text { (movement, namely } \\
\text { "moving away") }\end{array}$ & $\begin{array}{l}\text { to move on 'to } \\
\text { leave a place after } \\
\text { staying there for } \\
\text { some time' }\end{array}$ & $\begin{array}{c}2 \\
(20 \%)\end{array}$ & $\begin{array}{l}\text { to move off 'to } \\
\text { leave a place' }\end{array}$ & $\begin{array}{c}2 \\
(18,2 \%)\end{array}$ \\
\hline 4. & $\begin{array}{l}\text { Abstract } \\
\text { (abstract usage) }\end{array}$ & $\begin{array}{l}\text { to trade on 'to use } \\
\text { smth. in order to } \\
\text { get an advantage } \\
\text { for yourself, esp. } \\
\text { in a dishonest or } \\
\text { unfair way' }\end{array}$ & $\begin{array}{c}2 \\
(20 \%)\end{array}$ & $\begin{array}{l}\text { to trade off 'to } \\
\text { take advantage } \\
\text { of smth., usu. } \\
\text { by turn' }\end{array}$ & $\begin{array}{c}2 \\
(18,2 \%)\end{array}$ \\
\hline 5. & $\begin{array}{l}\text { Emotive } \\
\text { (causation of feeling) }\end{array}$ & $\begin{array}{l}\text { to put on 'to } \\
\text { bother, to irritate' }\end{array}$ & $\begin{array}{c}2 \\
(20 \%)\end{array}$ & $\begin{array}{l}\text { to tick off'to } \\
\text { bother, to irritate, } \\
\text { to make angry' }\end{array}$ & $\begin{array}{c}2 \\
(18,2 \%)\end{array}$ \\
\hline & Total & & $\begin{array}{c}10 \\
(100 \%)\end{array}$ & & $\begin{array}{c}11 \\
(100 \%)\end{array}$ \\
\hline
\end{tabular}




\section{Conclusion}

The present research enables to make some interesting generalizations. Notwithstanding initial opposition typical of $\mathrm{PhV}$-on and $\mathrm{PhV}$-off, which accounts for their allomorphism, the previously mentioned phrasal verbs, according to the analysis, can be characterized by the presence of isomorphic features as well.

3.1 Allomorphism becomes apparent mostly within the semantic system of PhV-on and PhV-off. Detailed semantic classification of these verbal complexes demonstrates that

1) $\mathrm{PhV}$-off are endowed by more versatile semantics (compare 22 specific meanings for PhV-off and 16 specific meanings for $\mathrm{PhV}$-on, see also 2.1.2) mainly due to different qualitative and quantitative level of the semantic structure development of postpositives (PC-off has a wider semantic structure than PC-on);

2) the principal spatial meanings of postpositives on and off 'onto the surface' (PC-on) and 'away from the surface' (PC-off) stand for antonymic relations between $\mathrm{PhV}$-on and $\mathrm{PhV}$-off that can be observed within three types of these phrasal verbs, namely locative and phasal $\mathrm{PhV}$-on/off as well as $\mathrm{PhV}$-on/off of functioning that belong to verbs of physical action (see also 2.2.1).

Allomorphic features within the derivational systems of the phrasal verbs under analysis are of minor scale compared to semantic allomorphism: 1) PhV-on and PhV-off have different productivity degree for wordforming models and 2) $\mathrm{PhV}$-off are characterized by more developed system of semantic derivation (see also 2.3.2).

3.2 Isomorphism within the systems of PhV-on and PhV-off can be traced equally both within semantic and derivational systems of these verbal combinations. In terms of semantics they have common typical meanings of physical action, mental-psychological action, abstract action, emotive action, possession, phase of the action, relativeness and existence. $\mathrm{PhV}$-on and $\mathrm{PhV}$-off differ only in two typical meanings - verbs of sense perception for $\mathrm{PhV}$-on and physiological verbs for PhV-off (see also 2.1.1).

The principal derivational feature in common for $\mathrm{PhV}$-on and $\mathrm{PhV}$-off is that derivational processes for both of them occur in two directions: 1) the formation of these verbal derivatives with the help of word-building derivation manifested through explicit and implicit motivation ( $\mathrm{PhV}$-on/off are 
formed from basic verbs by means of PC-on/off) and 2) the development of the semantic structure of these units by means of semantic derivation (the meanings of PhV-on/off develop from the meanings of PhV-on/off which already exist in the direction of their metaphorization, narrowing, widening or modification by additional semes). Semantic correlations between PhVon/off and their basic verbs in this respect fall into 3 following types: the relations of derivation, the relations of idiomatic character, the relations of equivalence, the most productive of which being the relations of derivation owing to the original derivative nature of these lexical units (see also 2.3.1).

\section{References:}

1. Amosova, N.N. (1963). Osnovy anglijskoj frazeologii [The Outline of English Phraseology]. Leningrad: Izd-vo LGU, 208 p.

2. Anichkov, I.E. (1961). Adverbial'nye poslelogi v sovremennom angliiskom yazyke [Adverbial Postpositions in Modern English]. Uchen. zap. Pyatigorskogo gos. ped. in-ta. no. 24, pp. 221-253.

3. Basyrov, Sh.R. (2004). Tipologiya glagolov s refleksivnym kompleksom v indoevropeiskikh yazykakh [Typology of Verbs with Reflexive Complex in IndoEuropean languages]. Donetsk, $351 \mathrm{p}$.

4. Berlizon, S.B. (1958). Sochetaniya tipa to go in, to cry out, to speed up, to give up v sovremennom angliiskom yazyke [Combinations like to go in, to cry out, to speed up, to give up in Modern English]. Inostr. yazyki v shkole, no. 6, pp. 9-24.

5. Vorob'jova, O.S. (2017). Semantika anglijskih frazovyh glagolov $s$ komponentami on i off [Semantics of English Phrasal Verbs with Components ON and OFF]. Rostov-na-Donu: Izd-vo Juzhn. fed. un-ta, 247 p.

6. Gurskij, S.E. (1975). Glagol'nye sochetanija tipa go out, melt away v sovremennom anglijskom jazyke [Verbal Combinations like go out, melt away in Modern English]. L'vov: Vishha shkola, 183 p.

7. Zhluktenko, Yu.A. (1954). O tak nazyvaemykh "slozhnykh glagolakh" tipa stand up v sovremennom angliiskom yazyke [On the so called "Compound Verbs" like stand up in Modern English]. Voprosy yazykoznaniya, no. 5, pp. 105-113.

8. Kaliushhenko, V.D. (1993). Semanticheskie i strukturnye priznaki glagolov i ih slovoobrazovatel'nye potencii [Semantic and Structural Features of Verbs and their Word-building Potencies]. Vzaimodejstvie leksiko-semanticheskih $i$ valentnostnyh svojstv glagolov v nemeckom i anglijskom jazykah. Vologda: Rus', pp. 20-28.

9. Klijunajte, I.A. (1989). Glagoly s postverbom out v anglijskom jazyke [Verbs with Postverbal Component OUT in English]. Minsk, 23 p.

10. Stupak, I.V. (2011). Strukturno-semantichni ta funkcional'ni harakteristiki pohidnih kauzativnih diesliv u nimec'kij i ukrä̈ns'kij movah [Structural, Semantic and Functional Characteristics of Derived Causative Verbs in German and Ukrainian]. Donetsk, 470 p. 
11. Trubnikova, E.V. (2015). Prostranstvennaja semantika anglijskih frazovyh i russkih pristavochnyh glagolov: sopostavitel'nyj aspekt [Spatial Semantics of English Phrasal and Russian Prefixal Verbs: Contrastive Study]. Vestnik Tomskogo gosudarstvennogo universiteta. 394, 66-73. URL: https://cyberleninka.ru/article/v/ prostranstvennaya-semantika-angliyskih-frazovyh-i-russkih-pristavochnyhglagolov-sopostavitelnyy-aspekt (accessed: 31.10.2016).

12. British National Corpus (BNC). URL: http://corpus.byu.edu/bnc (accessed: 30.10.2019).

13. Collins Cobuild Dictionary of Phrasal Verbs (1996). 492 p.

14. Dictionary of Slang and Unconventional English (2002). New York, $1400 \mathrm{p}$.

15. Kaliuščenko, V.D. (2000). Typologie denominaler Verben [Typology of Verbs Motivated by Nouns]. Tübingen: Max Niemeyer Verlag, 253 p.

16. Longman Dictionary of Phrasal Verbs (2000). Longman: Pearson Education Limited, $608 \mathrm{p}$.

17. Marchand, H. (1967). On the Description of Compounds. Word. 23(1-3), $379-387$.

18. Oxford Dictionary of Current Idiomaric English / by Cowie A., Mackin R. (1990). Oxford, $698 \mathrm{p}$.

19. Talmy, L. (1991). Path to Realization: A typology of event conflation. Proceedings of the $17^{\text {th }}$ Annual Meeting of the Berkeley Society. Berkeley, California. 480-519.

20. Vorobyova, O. (2015). Derivation within English Phrasal Verbs. International Research Journal. 1 (32-3), 45-48. URL: https://research-journal.org/ wp-content/uploads/2015/02/1-3-32.pdf (accessed: 30.10.2019). 